Mineralogical Journal, Vol. 3, Nos. 5 \& 6, pp. 261-281, Aug., 1962

\title{
ON ORDER-DISORDER TRANSFORMATION AND STABILITY RANGE OF MICROCLINE UNDER HIGH WATER VAPOUR PRESSURE
}

\author{
TAKESHI TOMISAKA \\ Department of Earth Science, Faculty of Literature \\ and Science, Yamaguchi University
}

\begin{abstract}
The following experiments were carried out with potassium feldspar in order to determine the stability range in temperature and water vapour pressure and to clarify the mechanism of mutual transformation of monoclinic form (( $\mathrm{Al}, \mathrm{Si})$ disorder form) and triclinic form ((Al, Si) order form). Under water vapour pressures of 1500,2400 and 4000 atms. respectively, a natural microcline from Takamizu was treated at various temperatures rang. ing from $350^{\circ}$ to $700^{\circ} \mathrm{C}$. for up to $1000 \mathrm{hrs}$, and was examined if transformation into monoclinic phase took place or not. Under water vapour pressures ranging from 350 to 1000 atms., potassium feldspars were formed by $\mathrm{Na} \sim \mathrm{K}$ ion-exchange from the mixture of a natural low albite from Mitsuishi and aqueous solution of potassium chloride, and were examined whether it was monoclinic or triclinic. The stability ranges of monoclinic and triclinic forms were determined from the results of those experiments and sum. merized in a P.-T. diagram. Taking those results as well as the order-disorder states and the mode of occurrence of potassium feldspars in nature into consideration, it is concluded that most of the naturally occurring potassium feldspars have probably been formed under noneqtilibrium con* ditions and frozen into a metastable phase, and to bring them into the stable phase the catalytic action of water molecules is necessary.
\end{abstract}

\section{Introduction}

Natural potassium feldspars occur in four crystalline phases, namely, sanidine, common orthoclase, microcline and adularia. Of these natural occurrences, sanidine is a high-temperature phase, microcline and adularia low-temperature phases, and orthoclase an in. termediate one. 
From the results of the detailed X-ray surveys on the basis of Laves's space-group consideration ${ }^{10)}$ as well as of other standpoints, it is generally recognized that the structures of these potassium feldspars have order-disorder relations with respect to Al-Si distribution. However, a more detailed examination of the genetical relations and formation mechanisms of these feldspars may reveal complexity beyond such simple comprehension.

The facts that orthoclase and sanidine crystallize even at a low temperature within the stability range of microcline, and that most microcline is formed in consequence of transition from the monoclinic phase, were interpreted by J. R. Goldsmith" applying his " simplexity principle". Potassium feldspars in hydrothermal ore deposits or quartz vein are morphologically monoclinic with adularia tracht, and authigenic feldspars or sedimentary feldspars are also adularia, or morphologically triclinic microcline which is formed not by transformation but by crystallization. Those facts have led the present writer to experimental attempt to prove the following hypotheses on the formation of potassium feldspars.

(1) In the case of crystallization from melts, most of potassium feldspars crystallize in metastable state with disorder or short-range order Al-Si distribution, and subsequently transform into stable structural states when they are retained for long time at certain temperatures within the microcline stability range under high water vapour pressure ("thermal transition" through the influence of water vapour).

(2) As to the catalyzer of formation of the order form, some room is still left to doubt if there are some catalytic substances other than water vapour. Furthermore, there may be mechanisms other than thermal transition, to form the order form, that is, compositional transformation or replacement reaction.

(3) The mechanism of crystallization of potassium feldspars from hydrothermal solution and aqueous solution differs from that from melts under water vapour, and those differences of crystallization environments will influence the aggregation and mode of polymeriza- 
tion of chain or layer formed prior to crystallization.

J. R. Goldsmith and F. Laves) carried out an experimental study on the stability relations of triclinic and monoclinic potassium feldspars, especially on the stability range of microcline by determining the conversion temperature of microcline into sanidine under water vapour pressure. According to them, microcline converts into sanidine at a far lower temperature $\left(525^{\circ} \mathrm{C}\right.$.) under hydrothermal condition than under dry condition (above $1000^{\circ} \mathrm{C}$.). However, in their experiments, the hydrothermal conversion of microcline into sanidine was brought about by reprecipitation of the sanidine from dissolved microcline solution, while under dry condition it was brought about by diffusive transformation. Accordingly, the experiments do not seem to be suitable to determine the stability relation between microcline and monoclinic potassium feldspar and the temperature range of formation of microcline.

The present experimental work has been carried out to prove the hypothesis (1), and to clarify the stability range of microcline and the temperature-pressure condition of order-disorder thermal transition of potassium feldspar. The results are reported in this paper. The problems (2) and (3) are at present being experimentally investigated.

\section{Apparatus and experimental method}

The experiments have been carried out by the following two methods: (a) Experiments on diffusive thermal transition from microcline to monoclinic phase under various water vapour pressures (1500 4000 atms.); (b) Experiments on the formation of potassium feldspar by $\mathrm{Na} \sim \mathrm{K}$ ion exchange of low-temperature albite under various water vapour pressures $(350 \sim 1000$ atms.).

(a) Thermal transition of microcline under water vapour pressure.

As shown schematically in Fig. 1 (A), the apparatus is a simple squeezer, similar to the high-pressure equipment described by D. T. Griggs and G.C. Kennedy ${ }^{5}$. The confining pressure is produced by 
pressing two pistons together. The piston faces have a diameter of $2.1 \mathrm{~cm}$. The pistons used in the experiments were made of stellite. The pistons are pressed together by an oil-pressure pump. The sample is heated by an external furnace enclosing the piston and sample. The temperature is measured by a platinum-platinum rhodium thermocouple placed in a hole in one of the pistons. The gap between the tip of the thermocouple and the sample is about $4 \mathrm{~mm}$.

The sample $(1.0 \mathrm{gr}$.) to be exposed to high pressures is placed on a copper foil admixed with some drops of water (sample: water= $83: 17$ in weight). The copper foils are placed between the sample

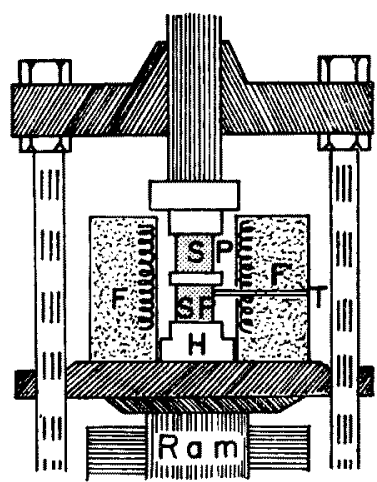

(A)

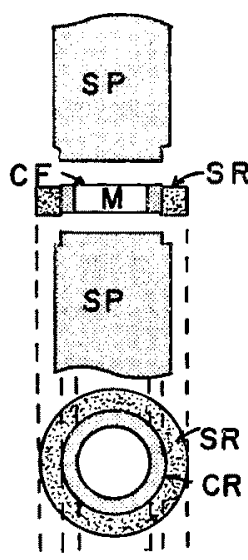

(B)

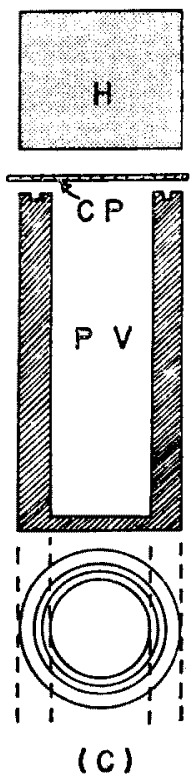

Fig. 1. Schematic diagram showing the apparatus for thermal transition under water vapour pressure.

(A) Cross section. (B) Exposed assembly showing stainless steel ring, copper ring, and copper foils $(\times 0.5)$. (C) Exposed assembly showing autoclave $(\times 0.5)$.

Ram: oil pressure ram. $T$ : thermocouple. $F$ : electric furnace. SP : stellite piston. SR : stainless steel ring. $\mathrm{H}$ : high speed steel holder. $C R$ : copper ring. $C F$ : copper foil. $M$ : sample. CP: cppper plate. PV : pressure vessel. 
and pistons to prevent the sample and volatiles from leaking outside. The sample between the foils thus pressed is considered to be under hydrostatic pressure. The geometry of a typical ring and sample assembly is shown in Fig. 1 (B).

A stainless steel ring is placed around the periphery of the copper ring to keep the sample and volatiles firm, and the copper ring is used to make the pressure of the sample and volatiles equal to that of piston. The copper foil and the copper ring are in direct contact. Thus, the test sample with water vapour is to be in a complete metal seal. The sample is first pressed up to the desired pressure and then the temperature is raised. In this experiment, the reprecipitation of microcline does not take place because the quantity of water in the sample is below twenty weight per cent.

Calibration of pressure gauge of the apparatus was made by observing the calcite-aragonite transition equilibrium established by J.C. Jamieson ${ }^{\text {) }}$ and G. J.F. MacDonald ${ }^{12}$. The range of error found in pressure reading was less than ten per cent.

b) Na $\sim K$ ion exchange of low-temperature albite under water vapour pressure.

The high pressure apparatus (Fig. 1 (A)) was provided with an autoclave as in Fig. 1 (C), which was set in place of the assembly (Fig. 1 (B)) of the stellite pistons and the stainless- and copper-ring. The water vapour pressure can be varied by adjusting volume of water in a pressure vessel, and the values of pressure are to be determined according to the variation diagram of specific volume of water $\left(\right.$ in $\mathrm{cm}^{3} / \mathrm{g}$.) versus temperature-pressure determined experimentally by W. T. Holser and G.C. Kennedy ${ }^{7}{ }^{8}$.

The sample $(1.5 \mathrm{gr}$ ) of low-temperature albite and the potassium chloride aqueous solution are put into the autoclave $(20 \mathrm{cc}$.), and potassium feldspar is formed under pressures ranging from 350 to 1000 atms. and at temperatures from $400^{\circ}$ to $600^{\circ} \mathrm{C}$. by exchange reaction of sodium ion in albite and potassium ion in solution.

Through these experiments the state of the distribution and 
mobility of Al-Si ion in the lattice of potassium feldspars which are formed under various pressures and temperatures may be examined.

\section{Samples}

Natural microcline and albite were used as starting materials. The microcline sample was collected from phenocrysts in porphyritic biotite granite from Takamizu, Kuga-gun, Yamaguchi Prefecture, Japan, and the albite, from crystal aggregates of albite vein in amphibolite from Mitsuishi, Hokkaido, Japan. The results of chemical analyses of the samples are shown in Table 1.

Table 1. Chemical compositions of microcline from Takamizu and albite from Mitsuishi.

\begin{tabular}{l|c|c} 
& Microcline from Takamizu & Albite from Mitsuishi \\
\hline $\mathrm{SiO}_{2}$ & $65.26 \%$ & $67.01 \%$ \\
$\mathrm{Al}_{2} \mathrm{O}_{3}$ & 18.53 & 20.30 \\
$\mathrm{Fe}_{2} \mathrm{O}_{3}$ & 0.58 & 0.16 \\
$\mathrm{FeO}$ & trace & trace \\
$\mathrm{TiO}_{2}$ & trace & trace \\
$\mathrm{CaO}$ & 0.32 & 0.95 \\
$\mathrm{MgO}$ & 0.32 & 0.20 \\
$\mathrm{~K}_{2} \mathrm{O}$ & 11.47 & 0.13 \\
$\mathrm{Na}_{2} \mathrm{O}$ & 3.30 & 11.01 \\
$\mathrm{H}_{2} \mathrm{O}(+)$ & 0.28 & 0.53 \\
$\mathrm{H}_{2} \mathrm{O}(-)$ & 0.09 & 0.17 \\
\hline Total & $100.15 \%$ & $100.46 \%$ \\
\hline Mol. ratio & Or $: \mathrm{Ab}: \mathrm{An}=68.46:$ & Or $: \mathrm{Ab}: \mathrm{An}=0.75:$ \\
& $29.94: 1.60$ & $94.74: 4.51$ \\
\hline
\end{tabular}

When the powdered samples are examined by a Geigerflex X-ray Diffractometer, moderately good $\mathrm{X}$-ray patterns are obtained. The $\Delta$ value (triclinicity) of the microcline is 0.8556 , and the $2 \theta_{131}-2 \theta_{1 \bar{s}_{1}}(\mathrm{Cu} K \alpha)$ of the albite is $1.10^{\circ} \sim 1.11^{\circ}$. 


\section{Experimental results}

The results of the experiments on the determination of triclinicmonoclinic stability range or the order-disorder relation in Al-Si distribution of potassium feldspar are described in Tables 2 and 3.

(a) Diffusive transition of microcline under higher water vapour pressure. The experimental results under higher water vapour pressures are summarized in Table 2 , in which are shown the temperature and pressure and their duration time in each experiment, and $\Delta$ value (triclinicity) of the product. These results are shown diagrammatically in Fig. 2.

Table 2. The relation between $\Delta$ value and temperature, pressure and time.

\begin{tabular}{|c|c|c|c|}
\hline $\begin{array}{c}\text { Temperature } \\
\left({ }^{\circ} \mathrm{C}\right)\end{array}$ & $\begin{array}{l}\text { Pressure } \\
\text { (atms.) }\end{array}$ & $\begin{array}{l}\text { Time } \\
\text { (hours) }\end{array}$ & $\begin{array}{c}\Delta \text { Value } \\
\text { (triclinicity) }\end{array}$ \\
\hline $\begin{array}{l} \\
500 \\
500 \\
500 \\
500\end{array}$ & $\begin{array}{l}\overline{4000} \\
4000 \\
4000 \\
4000\end{array}$ & $\begin{array}{l}\overline{120} \\
300 \\
600 \\
750\end{array}$ & $\begin{array}{l}0.8556 * \\
0.9510 \\
0.9448 \\
0.9000 \\
0.8500\end{array}$ \\
\hline $\begin{array}{l}485 \\
485 \\
485 \\
485 \\
485\end{array}$ & $\begin{array}{l}\overline{4000} \\
4000 \\
4000 \\
4000 \\
4000\end{array}$ & $\begin{array}{r}90 \\
225 \\
400 \\
600 \\
900\end{array}$ & $\begin{array}{l}0.8556^{*} \\
0.9230 \\
0.9545 \\
0.9530 \\
0.9400 \\
0.9100\end{array}$ \\
\hline $\begin{array}{l}60 \\
460 \\
460 \\
460 \\
460\end{array}$ & $\begin{array}{l}\overline{4000} \\
4000 \\
4000 \\
4000 \\
4000\end{array}$ & $\begin{array}{r} \\
60 \\
165 \\
420 \\
700 \\
1000\end{array}$ & $\begin{array}{l}0.8556 * \\
0.9025 \\
0.9400 \\
0.9420 \\
0.9445 \\
0.9435\end{array}$ \\
\hline $\begin{array}{l}350 \\
350\end{array}$ & $\begin{array}{l}\overline{4000} \\
4000\end{array}$ & $\begin{array}{r} \\
420 \\
1000\end{array}$ & $\begin{array}{l}0.8556^{*} \\
0.8575 \\
0.8575\end{array}$ \\
\hline $\begin{array}{l}700 \\
700 \\
700 \\
700\end{array}$ & $\begin{array}{l}\overline{2400} \\
2400 \\
2400 \\
2400\end{array}$ & $\begin{array}{r}5 \\
15 \\
30 \\
45\end{array}$ & $\begin{array}{l}0.8556^{*} \\
0.9175 \\
0.9600 \\
0.9775 \\
0.9250\end{array}$ \\
\hline
\end{tabular}


Table 2 (cont.)

\begin{tabular}{|c|c|c|c|}
\hline $\begin{array}{l}700 \\
700\end{array}$ & $\begin{array}{l}2400 \\
2400\end{array}$ & $\begin{array}{r}70 \\
100\end{array}$ & $\begin{array}{l}0.8413 \\
0.7750\end{array}$ \\
\hline $\begin{array}{l}600 \\
600 \\
600 \\
600 \\
600 \\
600\end{array}$ & $\begin{array}{l}\overline{2400} \\
2400 \\
2400 \\
2400 \\
2400 \\
2400\end{array}$ & $\begin{array}{r} \\
20 \\
35 \\
70 \\
200 \\
300 \\
360\end{array}$ & $\begin{array}{l}0.8556 \% \\
0.8900 \\
0.9637 \\
0.9900 \\
0.8675 \\
0.8030 \\
0.7630\end{array}$ \\
\hline $\begin{array}{l}500 \\
500 \\
500 \\
500 \\
500\end{array}$ & $\begin{array}{l}\overline{2400} \\
2400 \\
2400 \\
2400 \\
2400\end{array}$ & $\begin{array}{r}70 \\
150 \\
250 \\
300 \\
600\end{array}$ & $\begin{array}{l}0.8550^{*} \\
0.9275 \\
0.9500 \\
0.9312 \\
0.9125 \\
0.7975\end{array}$ \\
\hline $\begin{array}{l}475 \\
475 \\
475 \\
475 \\
475 \\
475\end{array}$ & $\begin{array}{l}\overline{2400} \\
2400 \\
2400 \\
2400 \\
2400 \\
2400\end{array}$ & $\begin{array}{r} \\
65 \\
\mathbf{1 7 5} \\
200 \\
375 \\
665 \\
965\end{array}$ & $\begin{array}{l}0.8556 \% \\
0.9100 \\
0.9450 \\
0.9575 \\
0.9270 \\
0.9100 \\
0.8765\end{array}$ \\
\hline $\begin{array}{l}450 \\
450 \\
450 \\
450 \\
450 \\
450 \\
450\end{array}$ & $\begin{array}{l}2400 \\
2400 \\
2400 \\
2400 \\
2400 \\
2400 \\
2400\end{array}$ & $\begin{array}{r}50 \\
95 \\
200 \\
275 \\
400 \\
630 \\
1000\end{array}$ & $\begin{array}{l}0.8556 \% \\
0.8925 \\
0.9250 \\
0.9375 \\
0.9362 \\
0.9362 \\
0.9338 \\
0.9360\end{array}$ \\
\hline $\begin{array}{l}400 \\
400 \\
400 \\
400\end{array}$ & $\begin{array}{l}\overline{2400} \\
2400 \\
2400 \\
2400\end{array}$ & $\begin{array}{r} \\
150 \\
310 \\
700 \\
1000\end{array}$ & $\begin{array}{l}0.8556 * \\
0.8775 \\
0.9037 \\
0.9020 \\
0.9030\end{array}$ \\
\hline $\begin{array}{l}350 \\
350 \\
350 \\
350 \\
350\end{array}$ & $\begin{array}{l}\overline{2400} \\
2400 \\
2400 \\
2400 \\
2400\end{array}$ & $\begin{array}{r} \\
150 \\
300 \\
500 \\
700 \\
1000\end{array}$ & $\begin{array}{l}0.8556 * \\
0.8556 \\
0.8560 \\
0.8555 \\
0.8560 \\
0.8560\end{array}$ \\
\hline $\begin{array}{l}500 \\
500 \\
500\end{array}$ & $\begin{array}{l}\overline{1500} \\
1500 \\
1500\end{array}$ & $\begin{array}{r} \\
250 \\
600 \\
1000\end{array}$ & $\begin{array}{l}0.8556 * \\
0.9245 \\
0.8870 \\
0.7975\end{array}$ \\
\hline$\overline{460}$ & $\overline{1500}$ & $\overline{100}$ & $\begin{array}{l}0.8556 \\
0.8900\end{array}$ \\
\hline
\end{tabular}


Table 2 (cont.)

\begin{tabular}{l|l|l|l}
460 & 1500 & 250 & 0.9160 \\
460 & 1500 & 600 & 0.9130 \\
460 & 750 & 0.9030 \\
460 & 1500 & 0.8950 \\
\hline 1500 & -1000 & $0.8556^{*}$ \\
\hline 440 & -1500 & 250 & 0.8750 \\
440 & 1500 & 500 & 0.9060 \\
440 & 1500 & 700 & 0.9050 \\
440 & 1500 & 0.9060 \\
440 & 1500 & - & 0.9070 \\
\hline & & 400 & $0.8556 *$ \\
\hline 360 & 1500 & 700 & 0.8550 \\
360 & 1500 & 1000 & 0.8560 \\
\hline 360 & 1500 & & 0.8552 \\
\hline
\end{tabular}

* Triclinicity of the original sample.

From Fig. 2, the following conclusions will be obtained: under the water vapour pressure of 4000 atms., the microcline $(\Delta=0.945)$ is stable below $470^{\circ} \pm 5^{\circ} \mathrm{C}$, and the monoclinic potassium feldspar is stable above $470^{\circ} \mathrm{C}$; ; under the water vapour pressure of 2400 atms., the microcline $(\Delta=0.936)$ is stable below $460^{\circ} \pm 5^{\circ} \mathrm{C}$, and the monoclinic potassium feldspar is stable above $460^{\circ} \mathrm{C}$; and under the water vapour pressure of 1500 atms., the microcline $(\Delta=0.910)$ is stable below $450^{\circ} \pm 5^{\circ} \mathrm{C}$, and the monoclinic potassium feldspar is stable above $450^{\circ} \mathrm{C}$. The (Al, Si) order-disorder transition in potassium feldspar was not recognizable below about $370^{\circ} \mathrm{C}$. under water vapour pressure of from 1500 to 4000 atms., within the duration time capable in this experiment.

(b) High-low transformation of potassium feldspar produced by $N a \sim K$ ion exchange method from low-temperature albite under lower water vapour pressure.

The conditions and results of the experiment under lower water vapour pressure are summarized in Table 3 , in which are shown the temperature and pressure of each experiments, the length of duration of $\mathrm{Na} \sim \mathrm{K}$ ion exchange reaction, the grain sizes of the starting material, and the phase of the resulting products. They are summerized diagrammatically in Fig. 3. 


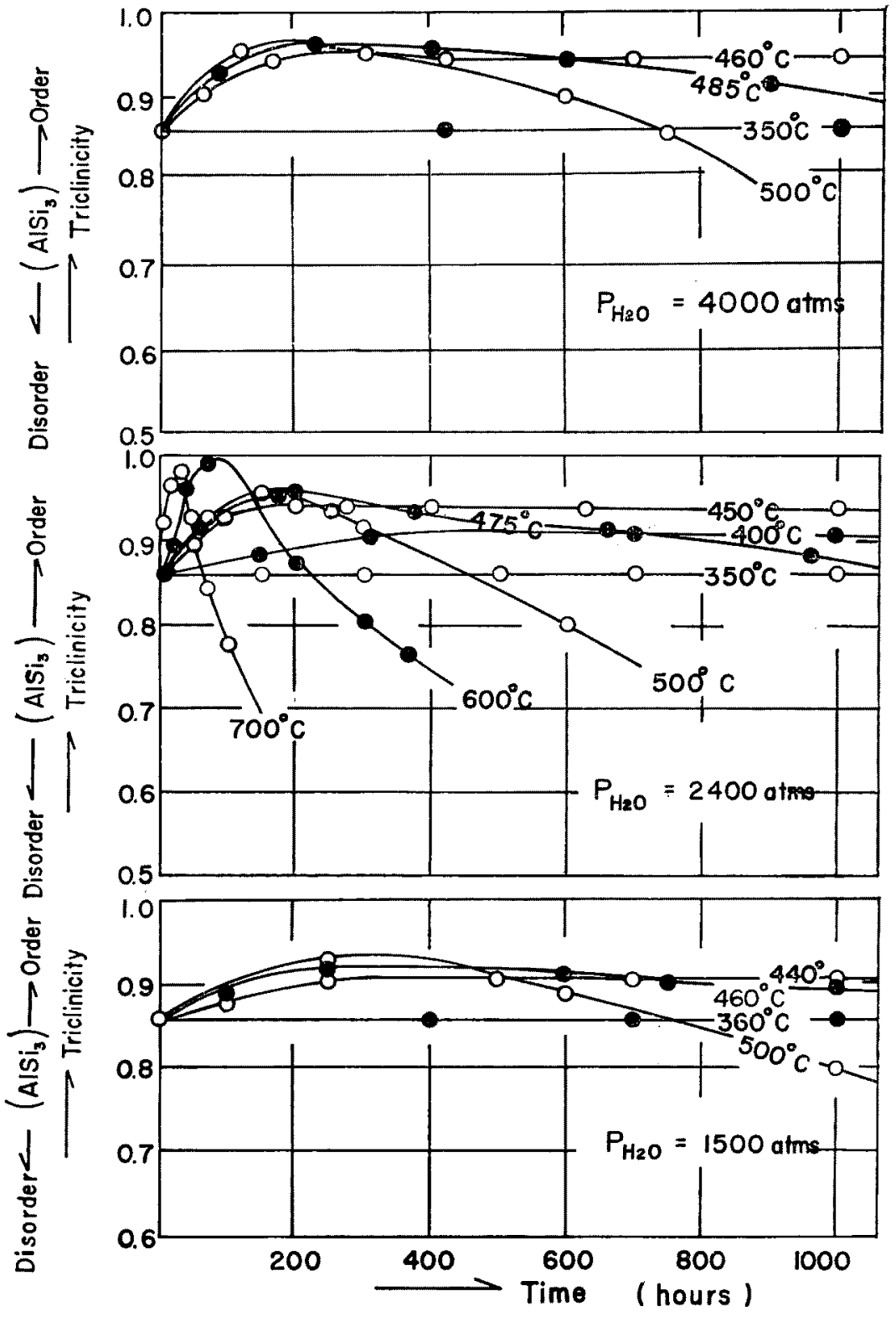

Fig. 2. The diagrams showing the relations between $\Delta$ value and time under respective pressures of 4000,2400 and 1500 atms., at temperatures from $350^{\circ}$ to $700^{\circ} \mathrm{C}$. 


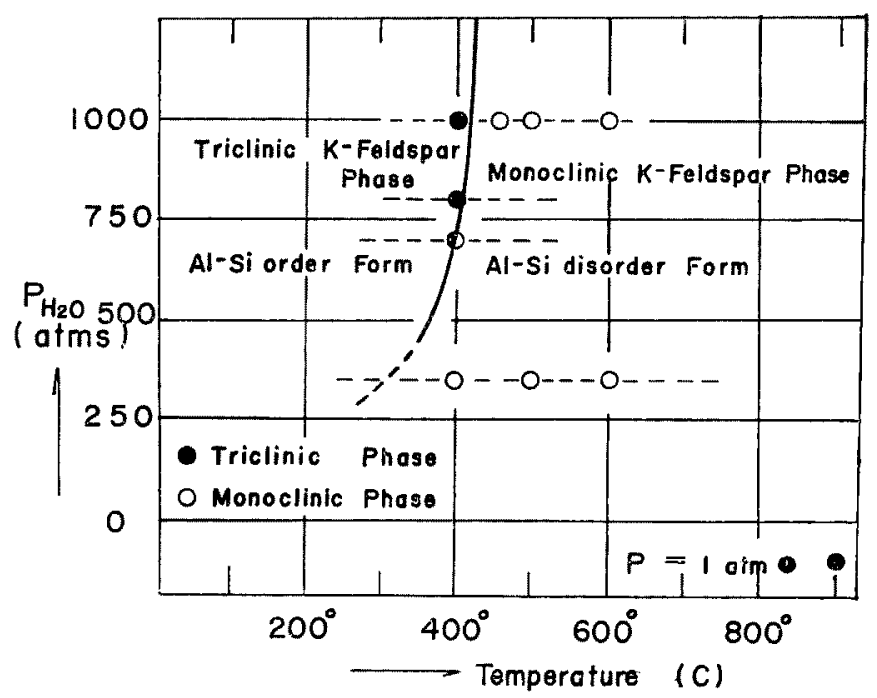

Fig. 3. The temperature-pressure diagram under a water vapour pressure of below 1200 atms., showing the stability relation of monoclinic -triclinic potassium feldspars.

Table 3. The relation between the phase of potassium feldspar and experimental conditions*.

\begin{tabular}{c|c|c|c|l}
\hline Temperature & $\begin{array}{c}\text { Pressure } \\
\text { (atms.) }\end{array}$ & $\begin{array}{c}\text { Time } \\
\text { (hours) }\end{array}$ & $\begin{array}{c}\text { Grain size of } \\
\text { starting material }\end{array}$ & $\begin{array}{c}\text { Phase of potas- } \\
\text { sium feldspar }\end{array}$ \\
\hline $600^{\circ} \mathrm{C}$ & 1000 & 200 & $100 \sim 150 \mu$ & monoclinic \\
500 & 1000 & 200 & $100 \sim 150$ & monoclinic \\
450 & 1000 & 300 & $100 \sim 150$ & monoclinic \\
400 & 1000 & 500 & $5 \sim 10$ & monoclinic \\
400 & 1000 & 1000 & $100 \sim 150$ & triclinic \\
400 & 800 & 500 & $5 \sim 10$ & monoclinic \\
400 & 800 & 1000 & $100 \sim 150$ & tric . $^{2}$ monoc. \\
400 & 700 & 1000 & $100 \sim 150$ & monoc. $>$ tric. \\
600 & 350 & 200 & $100 \sim 150$ & monoclinic \\
500 & 350 & 300 & $100 \sim 150$ & monoclinic \\
400 & 350 & 1000 & $100 \sim 150$ & monoclinic \\
\hline
\end{tabular}

1. Triclinicity $A=0.91$.

2. Triclinicity $\Delta=0.88$.

3. Triclinicity $\Delta=0.88$.

* $\mathrm{K}$ ion concentration in $\mathrm{KCl}$ aqueous solution is $0.1 \mathrm{gr} / \mathrm{cc}$. 
(c) P.-T. diagram.

The temperature-pressure diagram on triclinic-monoclinic stability relation in potassium feldspar which is based on the results of the experiments (a) and (b) is illustrated as Fig. 4. The hatched area

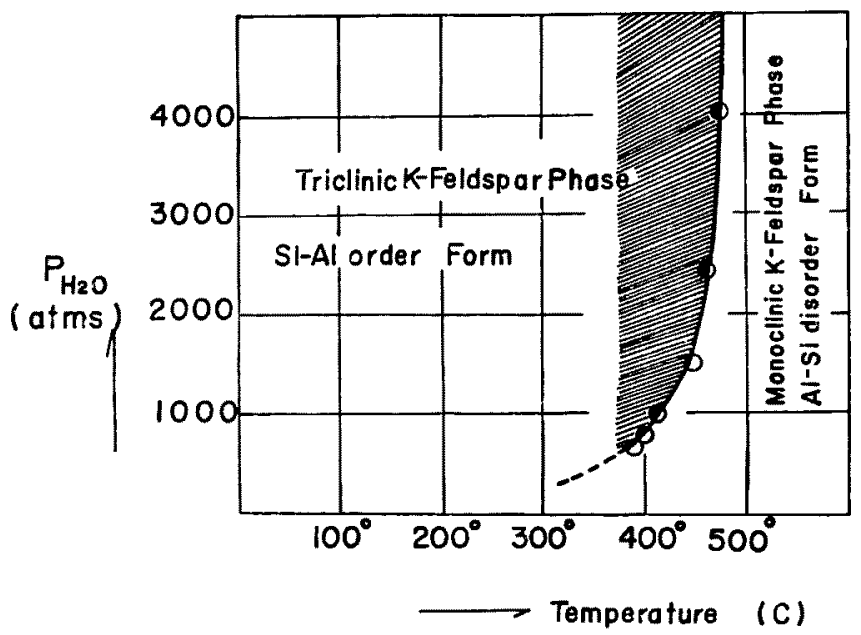

Fig. 4. The temperature-pressure diagram showing the stability relation of monoclinic-triclinic potassium feldspars.

in the Figure represents the P.- T. range which makes possible the transition into monoclinic from triclinic phase, while any appreciable transition does not take place when there is no water vapour, although the high form would be a thermodynamically stable one. This implies that the catalytic action of water molecule is important in highlow transition reaction in potassium feldspar.

(d) Na K ion exchange in dry condition.

From the mixture of powders of potassium chloride and low albite (or high albite), microcline (or monoclinic potassium feldspar) was produced by $\mathrm{Na} \sim \mathrm{K}$ ion exchange under atmospheric pressure at $850^{\circ}$ or $900^{\circ} \mathrm{C}$. This implies that the Al-Si distribution in the framework structure $\left[\mathrm{Al} \mathrm{Si}_{3} \mathrm{O}_{8}\right.$ ] of starting materials does not change under dry condition, even after alkali ion exchange, and that when the duration 
of exchange reaction is within one hundred hours, metastable microcline is formed even at a temperature as high as $850^{\circ}$ or $900^{\circ} \mathrm{C}$. The $\Delta$ value (triclinicity) of the produced microcline was 0.875 and the $\left(2 \theta_{131}-2 \theta_{1 \overrightarrow{1} 1}\right)(\mathrm{CuK \alpha})$ of the starting albite was $1.10^{\circ} \sim 1.11^{\circ}$. This result is also plotted in Fig. 3.

\section{Discussion and consideration}

The cell volumes and specific gravities of alkali feldspars calculated by $\mathrm{T}$. Tomisaka ${ }^{14}$ ) on the basis of the lattice constants are reproduced in Fig. 5. As is evident from the Figure, microcline is
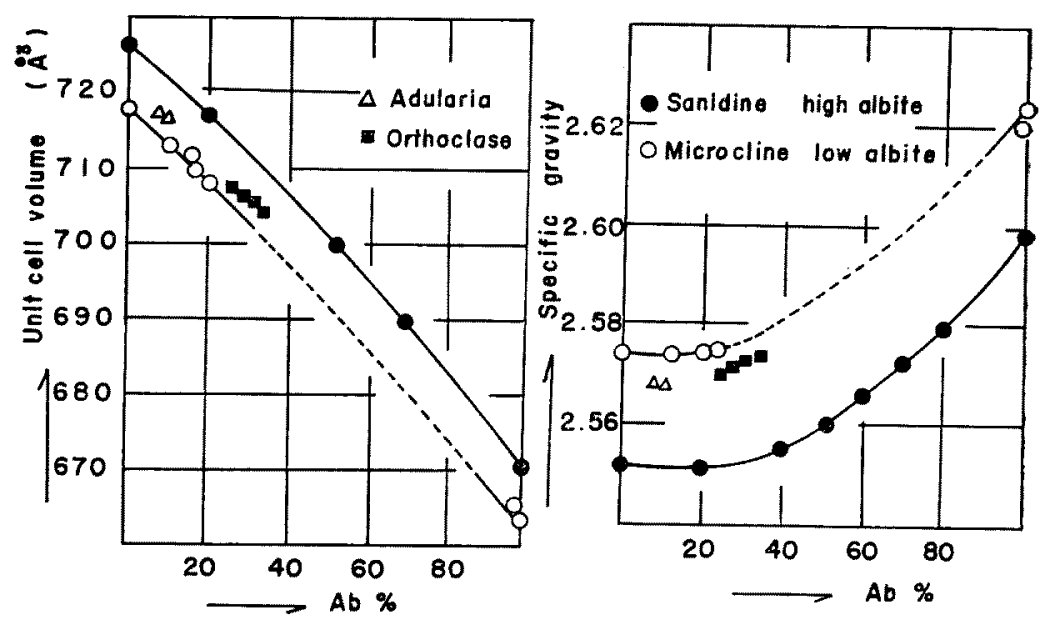

Fig. 5. The unit cell volumes and specific gravities of alkali feldspar.

denser than orthoclase and sanidine, and so it should be a high pressure form of orthoclase and sanidine. Since the microcline is converted slowly into orthoclase and sanidine by heating at a high temperature near the melting point, it should be a low temperature form of orthoclase and sanidine.

The mechanism of formation of microcline in nature present a 
puzzling problem in many respects, in spite of the established fact that microcline is a high pressure form of orthoclase and sanidine, and that sanidine is a high temperature form of orthoclase and $\mathrm{mi}$ crocline. Neither the attempt to synthesize microcline by a direct method, nor to convert orthoclase or sanidine into it, has been successful, except through the alkali ion-exchange of low albite. Therefore, the equilibrium relation of microcline-sanidine may hardly be determined by any direct method.

The mechanism in microcline $\rightleftarrows$ sanidine transition is a diffusive transition of $(\mathrm{Al}, \mathrm{Si})$ ion in the framework structure $\left[\mathrm{AlSi}_{3} \mathrm{O}_{8}\right.$ ] of feldspar. Since the $\mathrm{Si}-\mathrm{O}$ and $\mathrm{Al}-\mathrm{O}$ bonds in the network of $\left[\mathrm{SiO}_{4}\right]_{\infty}$ which is to be once broken at transition are very strong, the transition rate will be very slow. Thus, the reason why the effort at synthesis of microcline or conversion into microcline from orthoclase and sanidine in laboratory has been in vain, should be attributed to the deficiency of time of keeping temperature and pressure within the stability range of microcline.

It is considered that at the upper limit temperature of its stable region under a certain water vapour pressure, microcline may be converted into a higher order form, which in turn may become unstable at a higher temperature and transit into the monoclinic phase. With a view to confirming this consideration, J. R. Goldsmith and F. Laves ${ }^{4)}$ made an experiment and reported that a part of microcline was converted into sanidine at a temperature below $525^{\circ} \mathrm{C}$. without any flux other than water. As it was based on the reprecipitation of sanidine from the dissolved microcline solution, the data seem to be inadequate to determine the stability range of sanidine and microcline. And besides, in their experiment no attempt was made to clarify the variation of transition temperature in relation to water vapour pressure. Hence, the following consideration will be mainly based on the results of the writer's experiment summarized in Figs. 3 and 4. 
(1) Potassium feldspars formed under equilibrium and nonequilibrium conditions.

The high-low transition in feldspar is very sluggish, and consequently most feldspars seem to have been formed as a metastable phase under nonequilibrium condition. The order degree of (Al, Si) ion distribution in alkali feldspar depends upon the rate and temperature of crystallization, and upon the thermal history after crystallization.

The microcline from Takamizu under water vapour pressure displays an increase in the value of triclinicity at a temperature above $400^{\circ} \mathrm{C}$, and at $600^{\circ} \mathrm{C}$. it approaches $\Delta=1$ for a while. This may be regarded as an evidence for its formation under nonequilibrium condition and for its maintaining the metastable (Al, Si) ion distribution, which, in the process of the experiment, passed into a stable form.

In Figs. $6(\mathrm{~A})$ and $6(\mathrm{~B}), T_{0}$ denotes the critical temperature above which no long range order is observed. Under equilibrium conditions the intermediate states between order and disorder can appear only in the range of temperature between $T_{\mathrm{o}}$ and $T_{c}$, but, under nonequilibrium conditions it can appear at any temperature below $T_{\mathrm{c}}$. That is, under nonequilibrium conditions disordered material may possibly become partially ordered at temperatures below $T_{0}$, and ordered material may possibly become partially ordered at temperatures above $T_{1}$.

In Fig. $6(B)$, the state $S_{i}$ (triclinicity $\Delta=1$ ) is stable only at the temperature $T_{\mathrm{i}}$, and according to the results of the writer's experiment on thermal transformation the state $S_{*}(\Delta=0.910 \sim 0.945)$ is stable at the temperature $T_{\mathrm{k}}$. The accurate value of temperature difference between $T_{\mathrm{c}}$ and $T_{\mathrm{k}}$ cannot be determined by experiment, but the curve in Fig. 4 is presumed to shift slightly to the right in the state $S_{k}$. On the other hand, in the state $S_{i}$ the curve will shift slightly to the left. The compiled diagram is schematically illustrated as Fig. $6(\mathrm{C})$. 

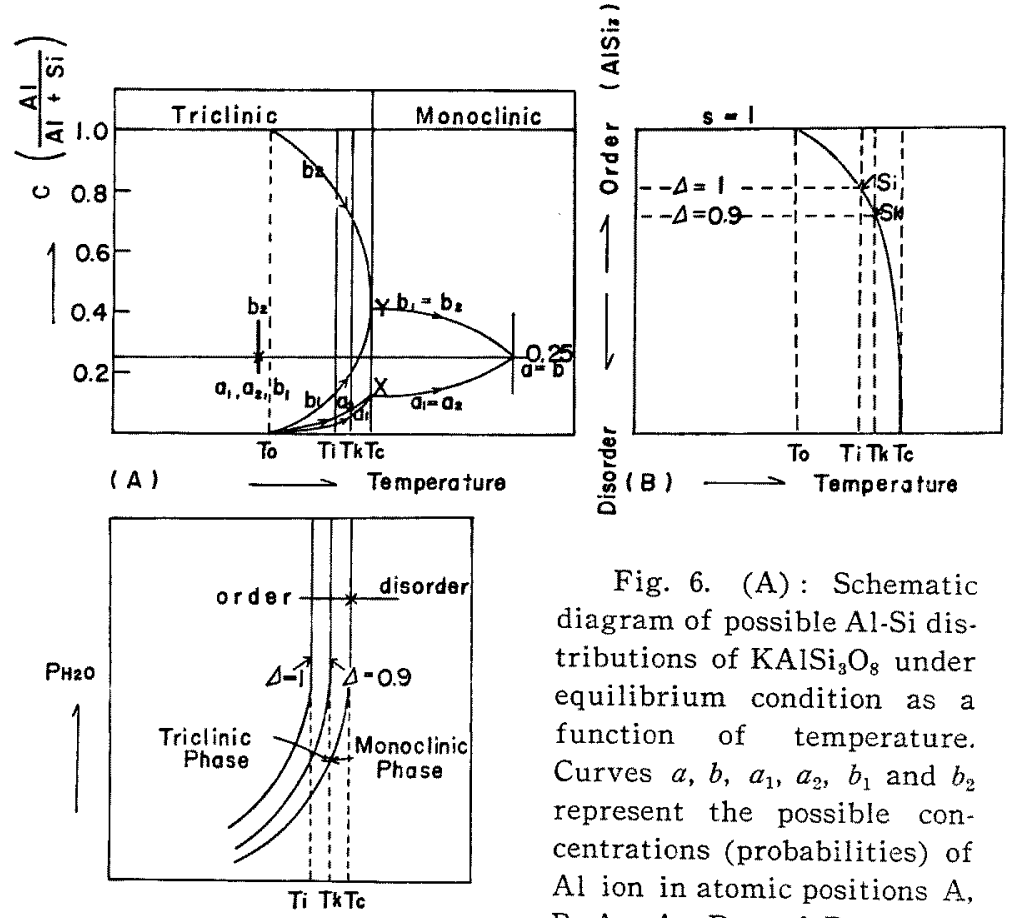

Fig. 6. (A) : Schematic diagram of possible Al-Si distributions of $\mathrm{KAISi}_{3} \mathrm{O}_{8}$ under equilibrium condition as a function of temperature. Curves $a, b, a_{1}, a_{2}, b_{1}$ and $b_{2}$ represent the possible concentrations (probabilities) of $A l$ ion in atomic positions $A$, (c)

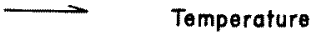
$B, A_{1}, A_{2}, B_{1}$ and $B_{2}$ respectively.

$$
\begin{aligned}
& C=\mathrm{Al} \text { ion concentration coefficient. } \\
& a+b=1 . \quad a_{1}+a_{2}+b_{1}+b_{2}=1 .
\end{aligned}
$$

(B) : Schematic diagram of order degree under equilibrium condition as a function of temperature.

$$
S=\text { long range order coefficient. }
$$

(C): Schematic diagram showing phase relation of potassium feldspar under equilibrium condition as functions of temperature and water vapour pressure.

(2) The mechanism and catalytic action in high-low feldspar transition. J. Wyart and G. Sabatier ${ }^{15)}$ 16) pointed out the following two experimental facts on the compositional transformation of alkali feldspar. First, under a high water vapour pressure, the potassium feldspar which is formed from low albite by compositional transformation is a monoclinic phase even at a temperature near $400^{\circ} \mathrm{C}$. 
Second, under atmospheric pressure, when water vapour is not pre* sent, the potassium feldspar which is formed from low albite by compositional transformation is a triclinic phase (microcline) even at a temperature as high as $900^{\circ} \mathrm{C}$. From these results, they advanced the view that to the determination of the stability range of highlow form of alkali feldspar, the presence of water vapour may be an essential prerequisite, and temperature may not be so. Thus, they emphasized the role of water molecules in the high-low transition of feldspar, and gave an experimental proof on the mobility of Al-Si ion in the lattice of feldspar under water vapour.

In the experiments of the present writer, too, when there was no water vapour, the rearrangement of $(\mathrm{Al}, \mathrm{Si})$ ions in the framework of $\left[\mathrm{AlSi}_{3} \mathrm{O}_{8}\right]$ did not occur, while, under high water vapour pressure, the rearrangement was performed easily. From those facts it is evident that there is a catalytic action of water molecules concern. ing the high-low transition of feldspar. Thus, it is concluded that the stability range of the monoclinic form of potassium feldspar is determined by pressure and temperature as shown in Fig. 3, and that water molecules play the role of catalyzer in bringing metastable phases of them into stable state. In this point, the present writer's opinion is different from that of J. Wyart and G. Sabatier whose experiments were not so detailed as to reveal the variation relation of water vapour pressure versus stability range.

J. Wyart, G. Sabatier and H. Curien ${ }^{17}$ presented a hypothesis on the action of water molecule. That is, the water molecule makes the bond of $\mathrm{Si}-\mathrm{O}-\mathrm{Si}$ or $\mathrm{Si}-\mathrm{O}-\mathrm{Al}$ open as follows:

$$
\begin{aligned}
& \mathrm{Si}-\mathrm{O}-\mathrm{Si}+\mathrm{H}_{2} \mathrm{O} \rightleftarrows \mathrm{Si}-\mathrm{OH}+\mathrm{HO}-\mathrm{Si} \text {, or } \\
& \mathrm{Si}-\mathrm{O}-\mathrm{Al}+\mathrm{H}_{2} \mathrm{O} \rightleftarrows \mathrm{Si}-\mathrm{OH}+\mathrm{HO}-\mathrm{Al} .
\end{aligned}
$$

In these formulas, the reaction toward the right leads to the opening of the bonds, and admits the rearrangement of ( $\mathrm{Si}, \mathrm{Al}$ ) ions in the framework of $\left[\mathrm{AlSi}_{3} \mathrm{O}_{8}\right]$ in the solid state, while the reaction toward the left closes the bond and expels the water molecule back. This hypothesis seems to be useful for us so far as the catalytic action 
of water molecule concerns.

(3) The genesis of naturally occurring potassium feldspar.

As to the mode of formation of potassium feldspar, the following points are easily deduced from previous investigations and the present experimental results.

(i) Even in the stability range of microcline, it usually crystallizes as a monoclinic phase (disorder form), and microcline may be formed through transformation when it is kept for a long time under a high water vapour pressure in the stability range of microcline.

(ii) In the stability range of monoclinic phase, it crystallizes as sanidine or orthoclase, and in case of a rapid fall in temperature or of absence of water vapour the monoclinic phase remains unchanged, but in case of a very slow fall in temperature under a high water vapour pressure, it is converted into microcline.

(iii) The rate of transformation is so slow at lower temperatures that the metastable monoclinic phase freezes itself without any change. The range in which the transition is practically performed, that is, the range of microclinization, is shown by hatched area in Fig. 4.

(iv) The transformation is practically impossible without the catalytic action of water molecules.

(v) If equilibrium is practically maintained during the crystallization of potassium feldspar, the stable phase will be crystallized.

The following facts are the summary of observation on the natural occurrence of potassium feldspars.

(i) Most microclines occurring in plutonic rocks, metamorphic rocks and pegmatite are usually morphologically monoclinic, and show a cross-hatched texture owing to fine polysynthetic albite and pericline twinning. This implies that they were crystallized as a monoclinic phase and subsequenty microclinized.

(ii) Adularias are usually monoclinic and rarely triclinic in morphology, and the distribution of Al-Si ion in them is assumed to be of order form but distinct from the case in microcline. As their par- 
ticular tracht suggests, their growth mechanism may be different from that of other potassium feldspars, and no subsequent microclinization is perceived with them.

(iii) Sanidine displays a typical disorder form in the distribution of Al-Si ions, while orthoclase is partially ordered.

(iv) Most authigenic potassium feldspars are microcline or adularia. The authigenic microcline is distinctly triclinic in morphology without cross-hatched twinning texture.

Especially noteworthy are the modes of formation of potassium feldspars in hydrothermal ore deposits and authigenic feldspars that are assumed to be formed below the critical temperature of water. According to F. Laves ${ }^{10)}$, and St. Hafner and F. Laves ${ }^{6)}$, adularia, which shows a particular tracht, is considered as having (Al, Si) distributions different from those of microcline. The considerations of G. W. DeVore ${ }^{2)}$ and T. Tomisaka ${ }^{13)}$ concerning the particular (Al, Si) distribution are as follows: polymerized chains have been formed prior to crystallization and the mode of the polymerization controls the tracht of feldspars, and it is assumed that the polymerized chains in the case of adularia differ from those in other potassium feldspars in the distribution of (Al, Si) ion. According to Y. Baskin ${ }^{1)}$, the formation temperature of authigenic microcline which is morphologically triclinic is not above $100^{\circ} \mathrm{C}$., but probably below it. It seems that very slow rate of growth is required to produce the microcline type (Al, Si) distribution, because laboratory attempts to synthesize microcline at lower temperatures have thus far been unsuccessful.

Experimentally, ion-exchange reactions take place rapidly and reversibly between alkali-bearing hydrous solutions and alkali feldspars at temperatures higher than $300^{\circ} \mathrm{C}$. and under pressures ranging from a few to thousands of atmospheres, and the high mobility of sodium and potassium ions during metamorphism or metasomatism is apparent in field evidences. Hence, the ion-exchange reaction between a water-rich fluid phase and feldspar may take place during 
metamorphism or metasomatism, producing alkali feldspar of order form at relatively low temperatures.

From those discussions it is easily understood that the formal application of the P.- T. phase diagram of Fig. 4 to the criteria of geothermometer or geopiezometer may cause mistakes. The mechanism and rate of crystal growth and transformation must be thoroughly studied previously, taking the catalytic action of water molecules into consideration.

\section{Summary and conclusion}

The experimental results of this study are summarized as follows:

(1) The microcline with the triclinicity $\Delta=0.945$, is stable under the water vapour pressure of 4000 atms. at about $470^{\circ} \mathrm{C}$., $\Delta=0.936$, under 2400 atms. at about $460^{\circ} \mathrm{C}$., and $\Delta=0.910$, under 1500 atms. at about $450^{\circ} \mathrm{C}$.

(2) The triclinicity of the microcline formed by $\mathrm{Na} \sim \mathrm{K}$ ion exchange from low albite, of which the $2 \theta_{131}-2 \theta_{1 \overline{3}_{1}}(\mathrm{CuK} \alpha)$ is $1.10^{\circ} \sim 1.11^{\circ}$, under atmospheric pressure at $900^{\circ} \mathrm{C}$. is $\Delta=0.875$.

(3) The triclinicity of the microcline formed by $\mathrm{Na} \sim \mathrm{K}$ ion exchanges from the mixtures of low albites $\left(2 \theta_{131}-2 \theta_{1 \overrightarrow{3} 1}(\mathrm{CuK} \alpha)=1.10^{\circ} \sim\right.$ $1.11^{\circ}$ ) and aqueous solution of potassium chloride is $\Delta=0.88$ under the water vapour pressure of 800 atms. at $400^{\circ} \mathrm{C}$., and is $\Delta=0.91$ under 1000 atms. at $400^{\circ} \mathrm{C}$.

The following conclusions have been reached from the experimental results and the previously revealed facts:

(1) The experimental results are summarized as the P.-T. diagram in Fig. 4. Since it is drawn on the basis of the data for the potassium feldspars with triclinicity of $0.880 \sim 0.945$, the true transition curve shifts slightly more to the right, and slightly more to the left for the potassium feldspar with triclinicity $\Delta=1$, as shown in Fig. 6 (C).

(2) The $(\mathrm{Al}, \mathrm{Si})$ ions in the framework of $\left[\mathrm{AlSi}_{8} \mathrm{O}_{8}\right]$ of potassium feldspar become mobile under catalytic action of water molecules at 
temperatures above $360^{\circ} \mathrm{C}$, but at lower temperatures the rearrangement of the ions is so sluggish that it cannot be performed in laboratory. Accordingly, the range of microclinization is limited within the hatched area in Fig. 4.

(3) Most potassium feldspars of natural occurrence are inferred to have been crystallized under nonequilibrium conditions, and frozen into a metastable phase.

\section{Acknouledgements}

The writer owes his sincere acknowledgement to Dr. N. Kawai of Kyoto University, who kindly helped him in constructing a squeezer indispensable to this investigation, and also to Messrs $T$. Ôtani and K. Takeda who assisted him in this experimental work. A part of the expense of this study was defrayed by a grant for scientific researches received from the Education Ministry of Japan; for this the writer expresses his gratitude.

\section{REFERENCES}

1) Baskin, Y.: Jour. Geology, 64, 132 (1956).

2) DeVore, G. W.: Jour. Geology, 64, 31 (1956).

3) Goldsmith, J. R.: Jour. Geology, 61, 439 (1953).

4) Goldsmith, J. R. and F. Laves: Geochim. et Cosmochim. Acta, 5, 1 (1954).

5) Griggs, D. T. and G. C. Kennedy: Amer. Jour. Sci., 254, 722 (1956).

6) Hafner, St. and F. Laves: Zeit. Krist., 109, 204 (1957).

7) Holser, W. T. and G. C. Kennedy: Amer. Jour. Sci., 256, 744 (1958).

8) Holser, W. T. and G. C. Kennedy: Amer. Jour. Sci., 257, 71 (1959).

9) Jamieson, J. C.: Jour. Chem. Phys., 21, 1385 (1953).

10) Laves, F.: Jour. Geology, 58, 548 (1950).

11) Laves, F.: Zeit. Krist., 113, 256 (1960).

12) MacDonald, G. J. F. : Amer. Miner., 41, 744 (1956).

13) Tomisaka, T.: Yamaguchi Journal of Science, 9, 11 (1958).

14) Tomisaka, T.: Science Reports of Yamaguchi University, 10, 21 (1959).

15) Wyart, J. and G. Sabatier: Bull. Soc. franç. Minér. Crist., 79, 444 and 574 (1956).

16) Wyart, J. and G. Sabatier: Bull. Soc. franç. Minér. Crist., 81, 223 (1958), 82, 216 (1959) and 83, 141 (1960).

17) Wyart, J., G. Sabatier and H. Curien: Bull. Soc. franç. Minér. Crist., 82, 387 (1959).

Manuscript received July 26, 1961. 